\title{
THE MAJOR TRENDS OF FOOD CONSUMPTION IN HUNGARY
}

\author{
Amelita Kata GÓDOR ${ }^{a}$ \\ ${ }^{a}$ Szent István University, Faculty of Economic and Social Sciences, Address: 2103, Gödöllő, Páter K. \\ u. 1., +36 70345 3448, Godor.Amelita@gtk.szie.hu
}

Cite this article: Gódor, A. K. (2016). The Major Trends of Food Consumption in Hungary. Deturope, 8, 3: $202-211$

\begin{abstract}
In the beginning of the 20th century the food consumption levels were much lower than later in the century, when food production increased as well. The selection of foodstuffs became wider and we can observe the modernisation of nutrition principles too, which both had a positive impact on consumption. The variety of food was also affected by the increasing life expectancy. The emergence of more modern ways in food consumption is halted not only by the traditions but by the fact that healthier foods are more expensive than fat or cereal prices. There is a significant correlation between the income levels and the quality of consumed food, as it can be observed that in different regions in Hungary. My aim was also to investigate the change in consumer behaviour in parallel with the increase of income levels; to see which sort of foods are preferred by the wealthier, and which are preferred by the ones with less income. It is also important to analyse the economic and social indicators on regional and other spatial levels and to compare them with food consumption. The annual net income per capita is usually higher in more developed regions than in the less developed ones. Therefore, the expenditure spent on better quality and more expensive food products is also higher. Similarly, in the case of the population there are differences in consumer habits according to purchasing power. For instance, for people with higher income one of the most important factors is to buy healthy and high quality food, but for the ones with lower income it can be a struggle only to find food in sufficient quantities, and quality cannot be as much of an issue. In the consumer basket, foodstuff accounts for approximately one-third of the overall expenditure. In this study I analysed the annual expenditure of Hungary's population on foodstuffs and the annual quantity of food consumed by households per capita on a regional level between 2010 and 2013.
\end{abstract}

Keywords: food consumption, regional territorial levels, food economics goal, structure of food consumption

\section{INTRODUCTION}

During the 20th century the Hungarian agricultural production was able to satisfy the food demand of the population. Thankfully, the more difficult times lasted for not so long, and after those the consumption levels rose to the previous levels, or even higher. At the beginning of the last century food consumption levels was significantly lower than later, as production levels increased throughout the century. The selection of food increased also and the principles of food consumption became more and more modern. The structure of food consumption was influenced by the growing average life expectancy as well. But the modernisation of consumption habits were hindered by traditions and the fact that healthier foods are more expensive as well There is a significant correlation between the income levels 
and the quality of consumed food. Within the domestic average the expenditure on food varied widely based on the income levels. From the 1960s the rapidly increasing production allowed higher consumption levels, which was even higher than the average of other European countries. However, the structure of consumption was still not optimal in every way.

After 1990 agricultural production levels dropped, food prices increased, and the food consumption levels decreased below the 1980s levels. On the other hand, the consumption of meat and egg rose to Western-European levels, especially in the case of poultry. It is an unfortunate situation that fish consumption is still below 3 kilograms per capita, despite the fact that Hungary has many lakes and rivers suitable for aquaculture. The role of fruits and vegetables had grown until about 25 years ago, but then it halted. (http://mek.oszk.hu)

\section{The situation and opportunities of food industry in Hungary}

Hungary is currently capable of self-sustainment on a $120 \%$ level. This level could be increased to $150 \%$ which may prove to be a valuable competitive advantage with the predicted rise of global food demand. The country possesses every factor needed to supply its population with domestic products and to increase its food export as well. (National Rural Development Strategy, 2012-2020)

Food industry is important for rural development and local economic development strategies, because

- $\quad$ the Hungarian food industry is the second largest employer among the processing sectors,

- $\quad$ it plays a significant role in providing jobs in rural areas,

- $\quad$ it is especially important for making settlements attractive for families and enterprises,

- $\quad$ to satisfy the local demand small-scale farmers process their own agricultural products

(National Rural Development Strategy, 2012-2020)

The importance of food production strategies is increasingly important, since the changes of demand and supply affect food prices, and through that, the choices of consumers as well.

The ratio of food is still high in the expenditure structure of Hungarian households $(24 \%$, while the EU average is only 13\%). This implies that the purchasing power is limited, and not that the population spends extreme amounts of money on food. Also, the food export - 
together with agricultural products - maintained its significant role. The domestic decrease of demand could be balanced out even with the export (Food Industry Strategy, 2014-2020)

On current prices the export revenues in 2004 and 2012 doubled but it was the result mostly of the exchange rate changes, which assumption is supported by the fact that the volume index increased only by 40\% in this particular time period. Between 2004 and 2012 the sector was financially loss-making, due to the large debts and therefore the expenditure on repayments (Food Industry Strategy, 2014-2020).

Promoting food industry is a general social policy aim; by exploiting the comparative advantages of the Hungarian food production and agroeconomy they become an important part of European food production. Food industry is a stable and competitive part of the Hungarian agro-sector, which does not only provide safe and secure food, but also contributes to increasing the well-being of the rural population (Food Industry Strategy, 2014-2020).

The national interest of Hungary:

- healthy, safe and reliable supply of the Hungarian population from Hungarian as much Hungarian resources as possible;

- producing the highest possible added value domestically by the optimisation of the food chain, and to improve the situation of the national economy by promoting export;

- preserving the self-sustainment abilities and jobs of rural areas, for example by promoting food-processing, and by developing sustainable food production systems. (Food Industry Strategy, 2014-2020)

\section{MATERIAL AND METHODS}

During the process of investigating the topic I used domestic literature (books and scientific papers) to analyse the spatial economic trends of rural areas and the food industry. My aim was to find out as much as possible about development strategies for rural areas and the food industry. I started my research with the following hypothesis: "The quality food consumption is more typical in the economically more developed areas, while the lagging behind areas, regions quality food consumption is not usual". The indicators I used were provided by high quality data which I acquired from Hungarian (the Regional Statistical Books, the Hungarian Central Statistical Office (KSH), the Research Institute of Agricultural Economics (AKI), the GFK Hungária research institute), and international sources (Eurostat, OECD studies, other internet sources). 


\section{RESULTS}

\section{Trends in food consumption}

I considered it important to investigate how the food consumption habits change along the changing income levels, and to see which types of food are preferred by the wealthier, and which are consumed by the poorer segments of the population. It is also important to analyse the economic and social indicators on regional and other spatial levels and to compare them with food consumption.

I found that the healthier premium-category food are clearly preferred by the population segment with greater purchasing power.

The net income per capita is higher in more developed counties than in lagging behind ones. This results the fact that the households of these regions spend more on more expensive and valuable food. The main concern of those with lower income is to purchase enough food, the ones with higher income levels deal with a different issue: to buy food not only in sufficient quantity, but with higher added value.

Figure 1 Purchasing power of the Hungary's counties, 2013

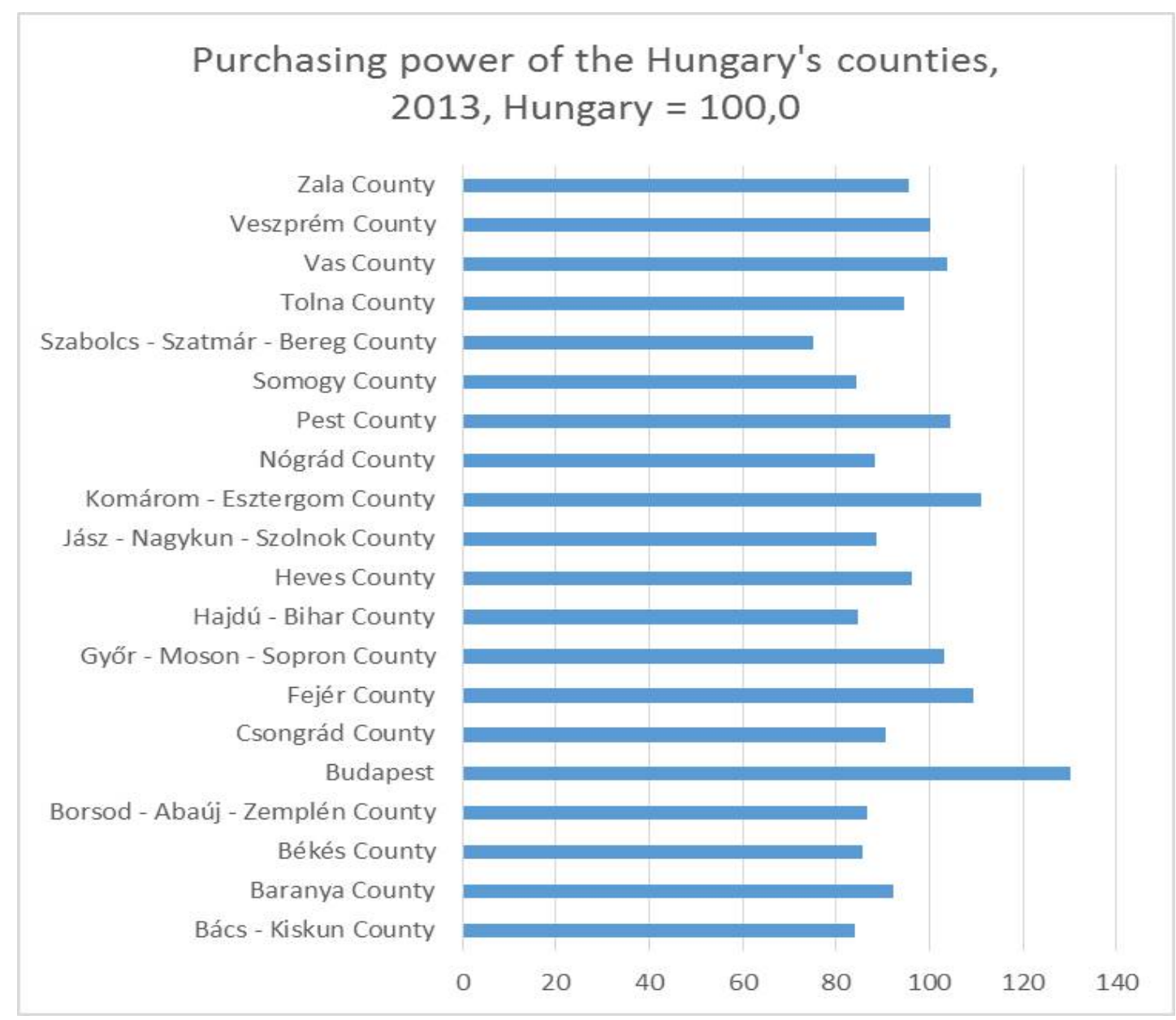

Source: GfK Vásárlóerő Magyarországon, 2013 
One of the most important tasks of agriculture is to provide food source on sufficient quality and quantity levels for a country. During the last few years the price level of staple food grew with $100-300 \%$ in Hungary. The expenditure on food play and important role in the life of households, and changes in price levels change the structure of the consumer's basket. The expenditure on food among all the goods is approximately one-third. However, life circumstances are affected not only by food prices, but also by the income levels. Consumer behaviour is influenced - beside the previously mentioned factors - by the inflation rate, the price of complementary products and some other micro- and macroeconomic factors (Szigeti, 2012)

In this study I investigated the percentage of income the population spends annually on foodstuffs, as well as the quantity of food consumed by households, per capita, on regional level between 2010 and 2013.

Figure 2 The main groups of expenditure per capita, 2010

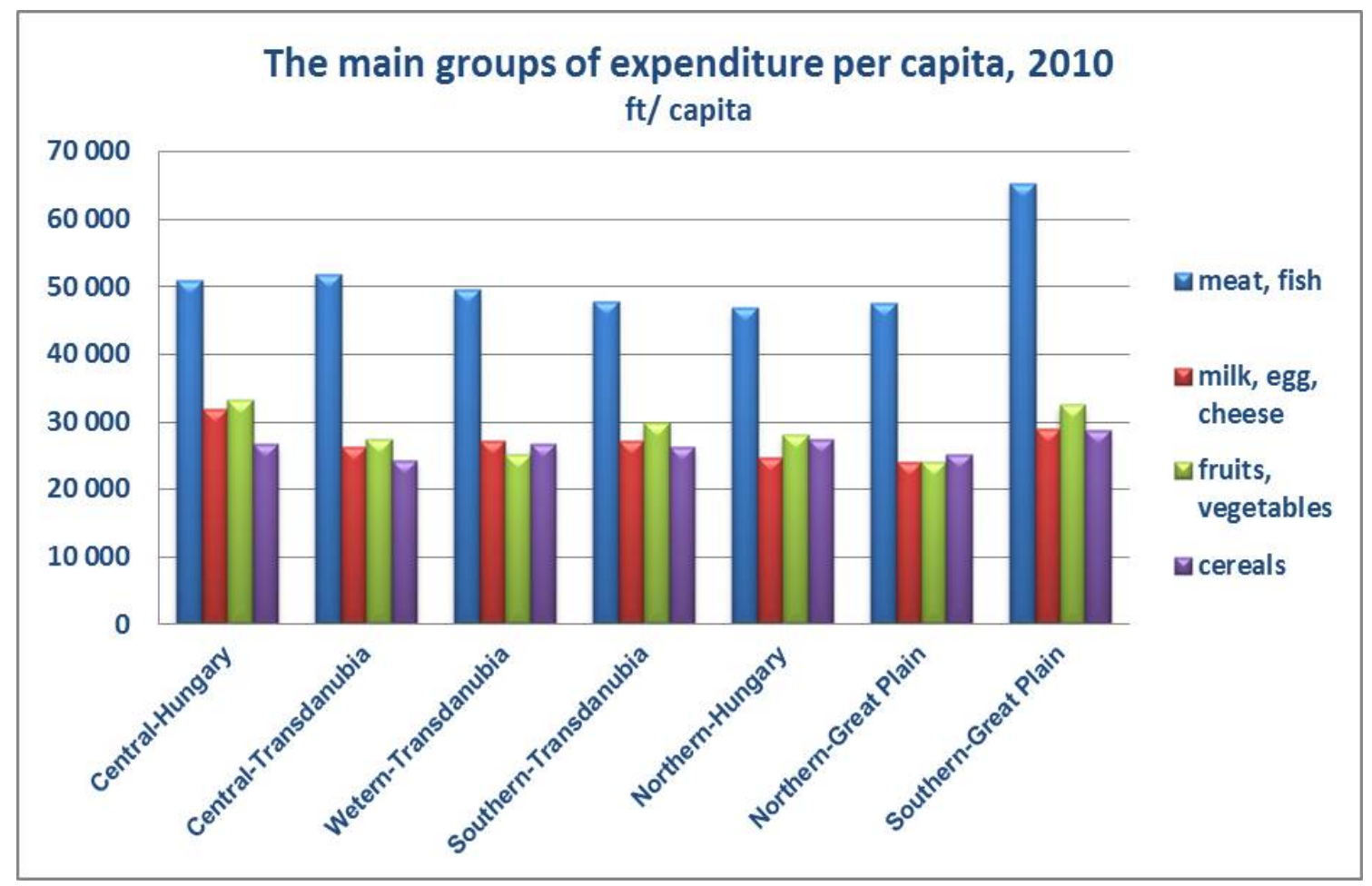

Source: Own editing based on data from Hungarian Central Statistical Office, 2013

The diagram above (Fig. 2) indicates that in 2010 the expenditure on vegetables and fruits is the highest in Central Hungary and in the Southern Great Plain, which shows a certain indication that people spend more on healthier food in these regions than in others. Compared to earlier years, food consumption increased in Northern Hungary. 
Figure 3 The main groups of expenditure per capita, 2011

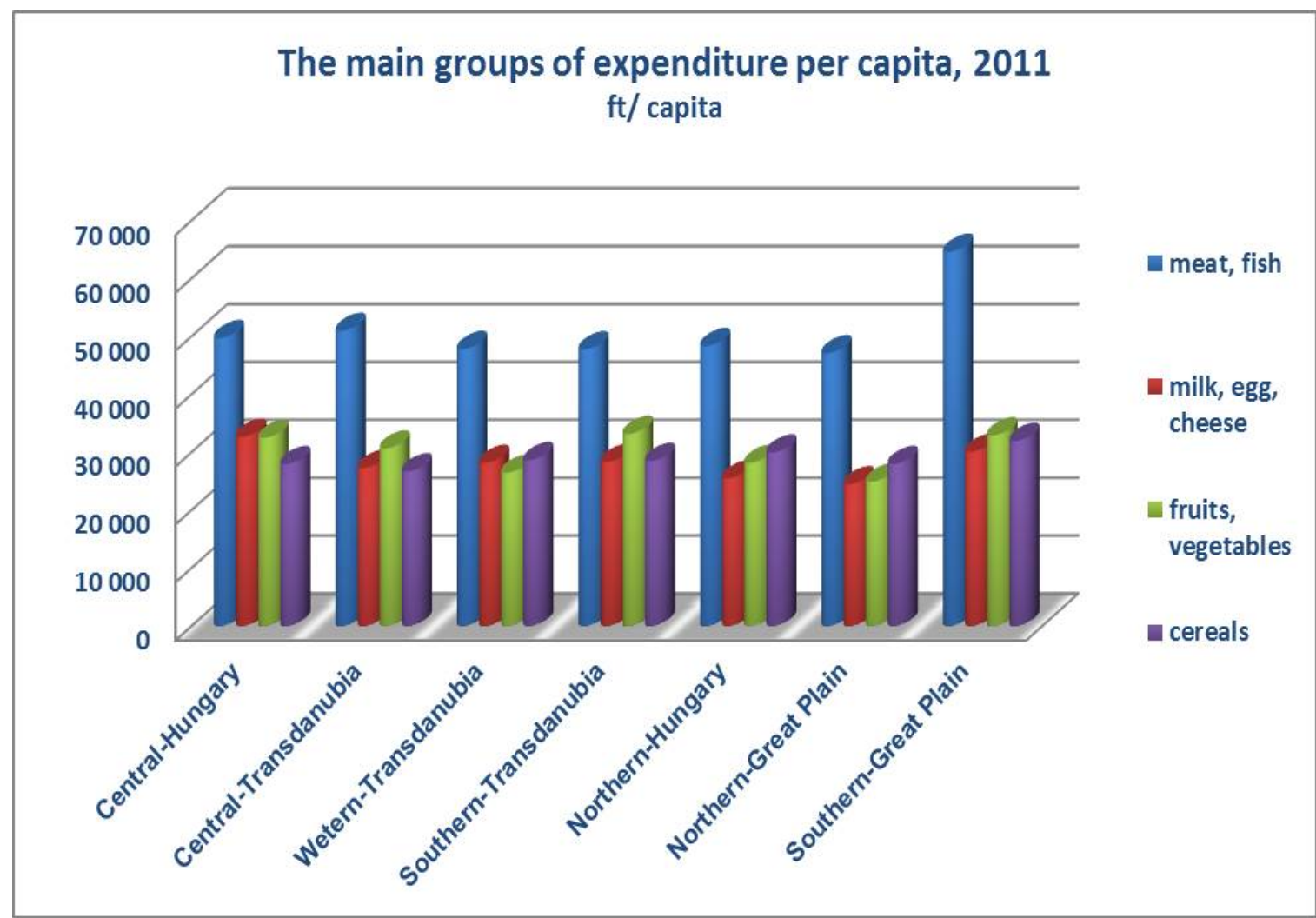

Source: Own editing based on data from Hungarian Central Statistical Office, 2013

The expenditure on meat and fish products is high in the Southern Great Plain (as it is indicated on the diagram above - Fig. 3). Based on the investigation of the data from 2010 and 2011 the expenditure on these goods is high in every other region compared to the rest of the examined products. However, this high level decreased and got really close to the levels other goods by 2012. Regarding to milk, eggs, cheese, fruits, vegetables and cereals we cannot observe significant changes.

When analysing these areas it must be taken into consideration that except for Central Hungary all the regions are convergence regions. It means that in these regions the GDP per capita value is lower than $75 \%$ of the average of the EU 25 countries, thus they can be considered lagging behind areas. 
Figure 4 The main groups of expenditure per capita, 2012

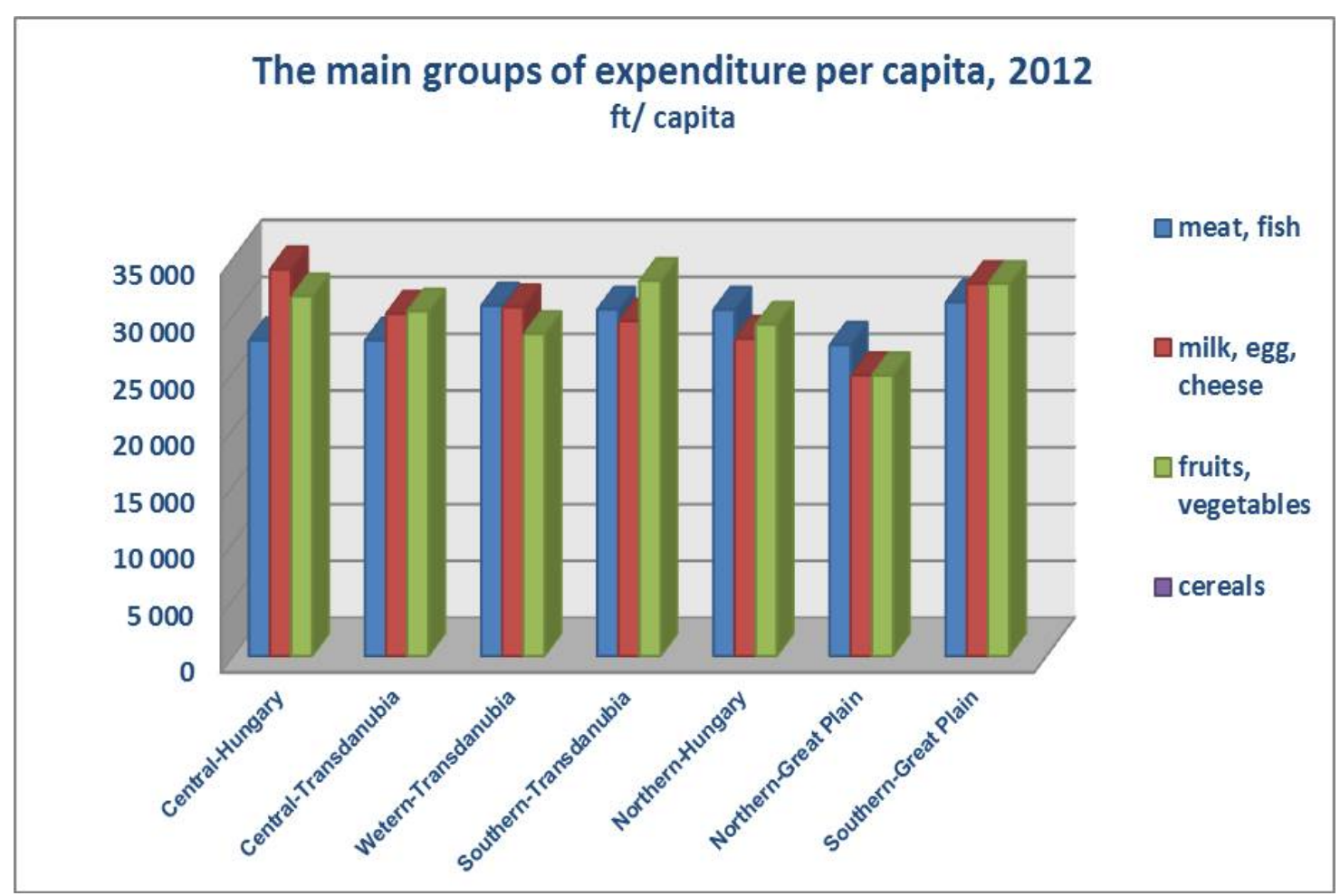

Source: Own editing based on data from Hungarian Central Statistical Office, 2013

On the diagrams below we can observe the quantity of food consumed in the households of regions in 2010, 2011 and 2012. We can see that in the households of Northern Hungary the quantity of consumed food is very low in the investigated years, and the results of Central Transdanubia and the Southern Great Plain support the outcomes of my previous analysis. It is clear that in 2010 Central Hungary indicated the lowest level of meat and fish consumption. This value did not change in 2011, but the consumption level of these goods dropped in Western Transdanubia compared to the previous years. The Southern Great Plain produced the highest consumption levels in both years. In 2010, the consumed amount was $71 \mathrm{~kg}$ per capita; in 2011 it was $67.8 \mathrm{~kg}$ per capita. 
Figure 5 The quantity of food consumed in the households, 2010

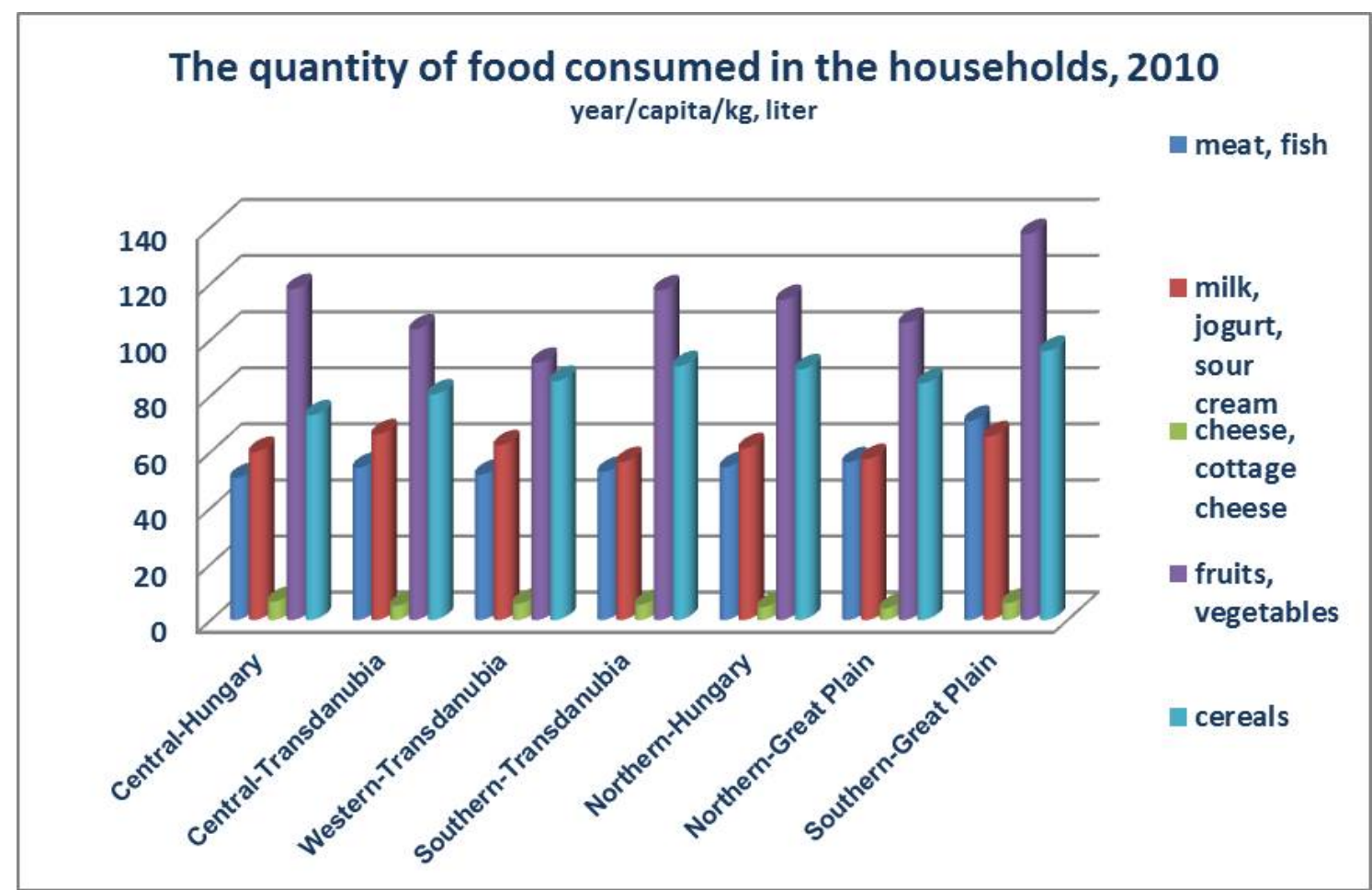

Source: Own editing based on www.ksh.hu

Considering the dairy products the very high consumption (66.2 $\mathrm{kg}$ per capita) of the Central Transdanubia region in 2010 shows a 10\% drop in the next year.

Fruit and vegetable consumption reflects the importance of health among the population a great deal. Based on this assumption, we can observe that in Western Transdanubia this indicator increased from $91.7 \%$ in 2010 to $98.4 \%$ in 2011 , but compared to other regions this result is low. The highest level of fruit and vegetable consumption can be observed in the Southern Great Plain with $137.6 \mathrm{~kg}$ per capita in 2010, and this amount decreased only to a small extent by 2011 (to $134.9 \mathrm{~kg}$ per capita).

We can observe that in Central Transdanubia the demand for fruits and vegetables is exceptional, and that the consumption value per capita is the highest in the Southern Great Plain which is probably the result of the fact that there is a large transit way going through the region. 
Figure 6 The quantity of food consumed in the households, 2011

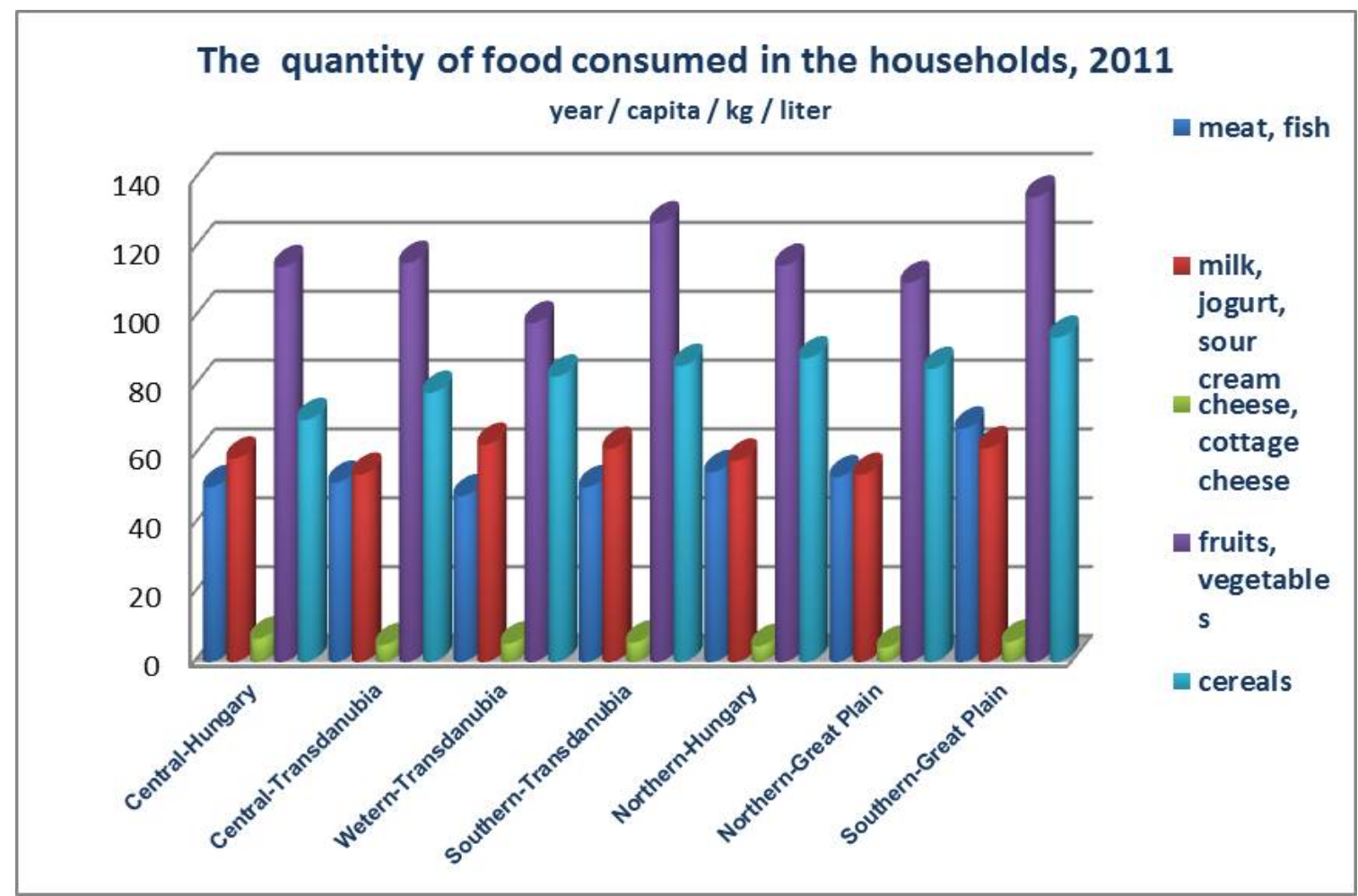

Source: Own editing based on data from Hungarian Central Statistical Office, 2013

Figure 7 The quantity of food consumed in the households, 2012

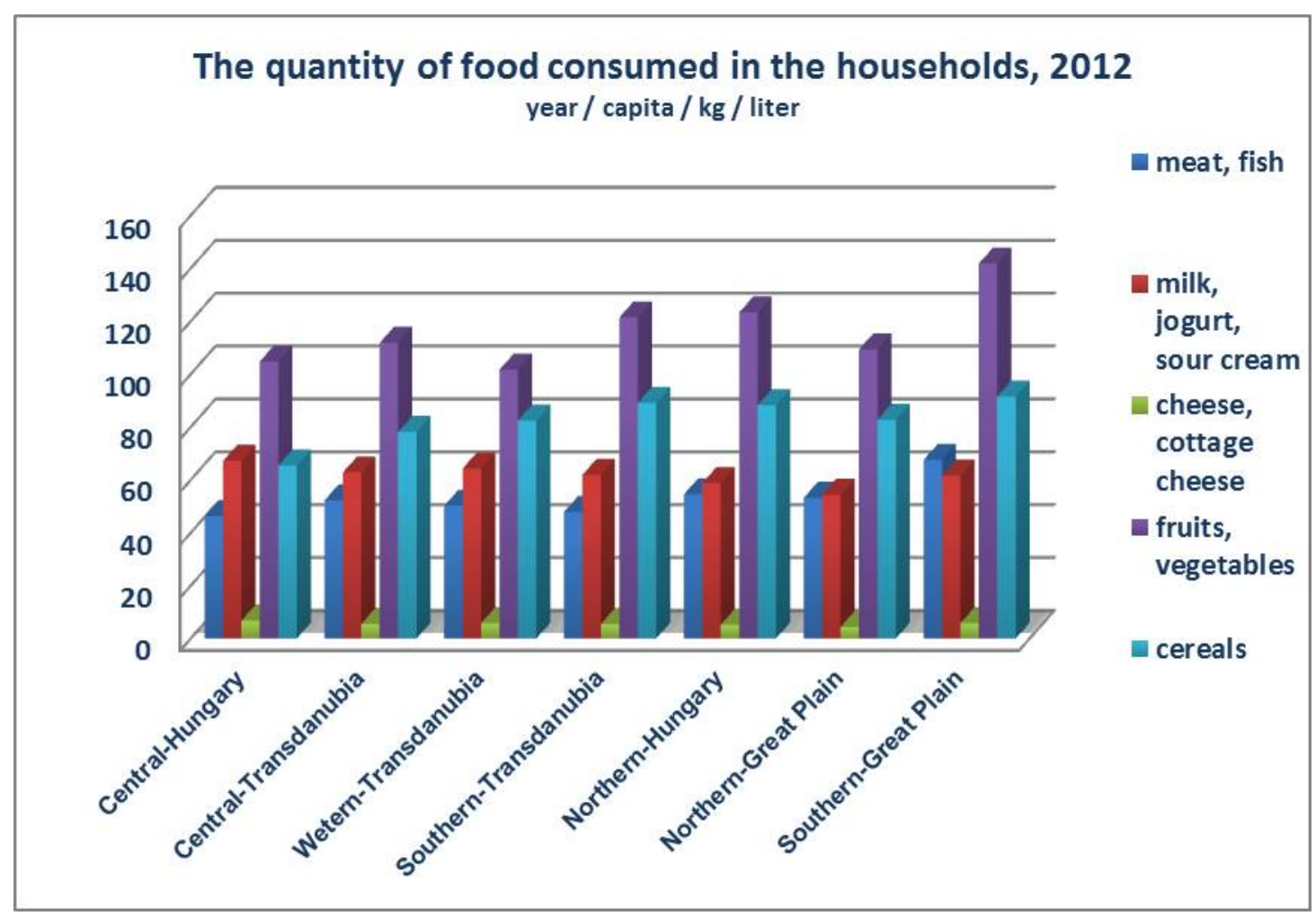

Source: Own editing based on data from Hungarian Central Statistical Office, 2013

Beside the above-mentioned factors, we can analyse food consumption according to education levels and residence as well. These two indicators influence the need for more sustainable and 
healthy products. In my opinion household consumption patterns are also affected by general lifestyle, and by the demographic trends in their regions, too.

The production value of the food industry increased with almost 30 percent (on current prices) between 2004 and 2012, although it means an approximately 14\% drop when taking the changes of volume. The volume of domestic selling decreased even more, with about $29 \%$.

\section{REFERENCES}

Élelmezésbiztonság. A magyar élelmiszer-gazdaság, a vidékfejlesztés és az élelmiszerbiztonság stratégiai alapjai, Hungarian Academy of Sciences, Budapest (2010)

Hungarian Central Statistical Office (2011). A háztartások fogyasztásának regionális különbségei, 2009. Központi Statisztikai Hivatal, 2011

Hungarian Central Statistical Office (2014). A háztartások fogyasztása, 2012. Statisztikai Tükör, Vol. 7., issue 100. (http://mek.oszk.hu)

National Rural Development Strategy 2012-2020, Ministry of Rural Development

Szigeti, J. (2012). Jóléti hatások vizsgálata a magyar élelmiszerfogyasztók körében, $\mathrm{PhD}$ thesis, BCE 